\title{
Clinical and autoantibody correlations in Orientals with systemic lupus erythematosus
}

\author{
M L BOEY, ${ }^{1}$ C L PEEBLES ${ }^{2}$ G TSAY ${ }^{2}$ P H FENG, ${ }^{1}$ AND E M TAN ${ }^{2}$ \\ From the ${ }^{1}$ Department of Medicine IV, Tan Tock Seng Hospital, Singapore; and ${ }^{2}$ Scripps Clinic and Research \\ Foundation, La Jolla, Ca
}

SUMMARY Serum samples from 94 patients with systemic lupus erythematosus (SLE) from $\frac{0}{2}$ medical unit in Singapore were analysed for autoantibodies of 10 different specificities. The prevalence of antibodies to the following antigens was as follows: double stranded (ds) DNA$(43 \%)$, histone $(81 \%)$, Sm (26\%), nuclear ribonuclear protein (nRNP) (32\%), SS-A(Ro) (63\%) SS-B(La) (12\%), SL/Ki (9\%), ribosomal RNP (rRNP) (16\%), p70/p80 (5\%), proliferating celpo nuclear antigen (PCNA) (3\%). Except for a higher prevalence of anti-SS-A(Ro), other autoantibodies were within the range reported from Western countries, indicating a high uniformity of autoantibody profiles in SLE in different countries. Patients with neuropsychiatrice manifestations showed a higher plurality of antibodies per patient than patients withou兒 neuropsychiatric symptoms, $4.22 v 2.77$. Patients with anti-Sm were more likely to have activeo lupus disease. There was no increased prevalence or specific type of autoantibody in those with renal manifestations.

Key words: antinuclear antibodies, central nervous system disease.

Systemic lupus erythematosus (SLE) is manifested by a polyclonal autoantibody response. In this disease antibodies to native DNA, histones, Sm, nuclear RNP, SS-A(Ro), and SS-B(La) are all present. Most patients with SLE have three or more autoantibodies in the serum. Certain antinuclear antibodies such as native DNA and Sm are highly specific for SLE and show good correlation with the disease. The titre of various antinuclear antibodies has been used to follow the response to treatment and the fluctuations of disease activity. This has been clearly shown for antibodies to native DNA in SLE. ${ }^{1}$

The purpose of this study was to employ newer diagnostic assays to determine the prevalence of defined autoantibodies in a large and carefully evaluated group of patients with SLE in a hospital in Singapore. The data were used to compare our findings with published data in Western countries and to determine the relations between autoantibodies and clinical features such as disease activity and neuropsychiatric symptoms.

Accepted for publication 15 March 1988.

Correspondence to Dr M L Boey, Department of Medicine IV, Tan Tock Seng Hospital, Moulmein Road, Singapore 1130.
Patients and methods

PATIENT SELECTION

Ninety four patients (86 women, eight men) with $\mathrm{a}^{\mathrm{P}}$ diagnosis of SLE were studied. Eighty three patients were Chinese, seven Malays, and four Indians. The patients met the revised criteria of the American Rheumatism Association for SLE. ${ }^{2}$

All patients attending the lupus clinic of Tan Tock Seng Hospital, Singapore had a detailed clinical and laboratory assessment. Clinical data were obtaines5 by review of hospital records. The following tests were done during the course of study: complete blood count, Westergren sedimentation rate, Rose Waaler test for rheumatoid factor, total haemolytic. complement $\left(\mathrm{CH}_{50}\right)$, and urine analysis. Patientso were reviewed for particular symptoms, signs, and laboratory abnormalities of SLE. Renal biopsieș were performed in 15 patients.

Disease activity as defined by Urowitz et al wase used. ${ }^{3}$ The presence of any two of the following seven features or groups of features constituted active disease: (a) arthritis; (b) laboratory abnor:malities - namely, positive LE cell preparation $\overline{0}$ white cell count $\angle 4 \times 10^{9} / 1$, decreased $\mathrm{CH}_{50}$ or $\mathrm{C3}$, of increased DNA antibody; (c) rash or mucous 
membrane ulcers or alopecia; $(d)$ pleuritis or pericarditis; (e) seizures, psychosis, organic brain syndrome, or lupus headaches; $(f)$ vasculitis; $(g)$ haematuria.

Serum samples of the patients were studied for the presence of antinuclear antibodies of 10 different specificities.

IMMUNOLOGICAL ASSAYS FOR DEFINED ANTINUCLEAR ANTIBODIES

Fluorescent antinuclear antibody

Serum samples were tested for fluorescent antinuclear antibody using a $\mathrm{HEp}_{2}$ cell substrate and a polyvalent conjugate. There were interpreted using a Leitz Ortholux II microscope with a $50 \times$ water immersion objective. Sera were considered positive if they gave a $1+$ reaction (scale of $1+$ to $4+$ ) at a $1: 40$ dilution.

\section{Immunodiffusion}

Serum samples were tested for antibodies to $\mathrm{Sm}$, nRNP, SS-A(Ro), SS-B(La), rRNP, SL/Ki, PCNA, and $\mathrm{Ku}(\mathrm{p} 70 / \mathrm{p} 80)$ by double immunodiffusion using $8 \mathrm{~mm}$ wells, $4 \mathrm{~mm}$ apart in a gel of $0.5 \%$ agarose (Seakem ME, FMC Corp), $1.5 \%$ polyethylene glycol $8000,0.1 \%$ sodium azide. ${ }^{4}$ The volume of serum used was $100 \mu$ l. The antigens used included a phosphate buffered saline soluble extract of calf thymus acetone powder and a whole cell sonicate of Wil-2 cells. Serum samples were tested at several dilutions next to standard prototypes.

Enzyme linked immunosorbent assay (ELISA)

Serum samples were tested for antibodies to native DNA and histone by ELISA according to the method of Rubin. ${ }^{5}$ In addition, the presence of antibodies to Sm, nRNP, SS-B(La), and PCNA, which were detected by immunodiffusion, were confirmed by ELISA. In contrast with DNA and histones, which can be obtained in highly purified form commercially, Sm, nRNP, SS-B(La), and PCNA cannot, and the preparation of these antigens was performed according to methods previously described from this laboratory. ${ }^{6-9}$ These antigens were used to coat wells of ELISA plates at the following concentrations: 'free' $\mathrm{Sm} 6 \mu \mathrm{g} / \mathrm{ml}, \mathrm{Sm} / \mathrm{RNP}$ complex $5 \mu \mathrm{g} / \mathrm{ml}$, SS-B(La) $5 \mu \mathrm{g} / \mathrm{ml}$, and PCNA $1 \cdot 3 \mu \mathrm{g} / \mathrm{ml}$.

\section{Immunoprecipitation}

Immunoprecipitation was performed as described previously. ${ }^{10}$ Briefly, monolayer Hela cells were grown in $150 \times 25 \mathrm{~mm}$ dishes (Falcon 3025) and labelled for 16 hours with $\left[{ }^{35}\right.$ S]methionine in methionine free Dulbecco's minimal essential medium at a concentration of $3.7 \mathrm{MBq} / \mathrm{ml}$. Cells were rinsed briefly with phosphate buffered saline and $1.5 \mathrm{ml}$ lysis buffer containing $150 \mathrm{mM}$ sodium chloride and $10 \mathrm{mM}$ trometamol (TRIS)- $\mathrm{HCl}$ $\mathrm{pH} 7 \cdot 2$. Nonidet P-40 (NP-40) $(0 \cdot 5 \%)$ was added to each plate and cells removed with scraping and pooled. Cells were allowed to remain for 10 minutes on ice for lysis to continue. The supernatant obtained by centrifugation at $10000 \mathrm{~g}$ for 10 minutes at $4^{\circ} \mathrm{C}$ was stored at $-70^{\circ} \mathrm{C}$ and used for antigen. The antigen was precleared before use by mixing $100 \mu \mathrm{l}$ of a $10 \%$ protein-A-Sepharose bead suspension, prepared by adding one vial of beads (Pharmacia) to $50 \mathrm{ml}$ NET-2 buffer

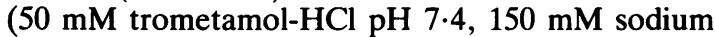
chloride, $5 \mathrm{mM}$ edetic acid), $0 \cdot 1 \%$ sodium dodecyl sulphate (SDS), $0.5 \%$ sodium deoxycholate, $0.5 \%$ $\mathrm{NP}-40,0.02 \%$ sodium azide containing $2 \mathrm{mg} / \mathrm{ml}$ bovine serum albumin, to each $1 \mathrm{ml}$ of extract, rotating at $4^{\circ} \mathrm{C}$ for 20 minutes, and centrifuging at $10000 \mathrm{~g}$ for 10 minutes with the subsequent removal of the supernatant for use in the assay. Patient samples were prepared by adding $10 \mu \mathrm{l}$ of sera to $500 \mu \mathrm{l}$ NET -2 and $100 \mu \mathrm{l}$ protein-A-Sepharose beads and rotating at $4^{\circ} \mathrm{C}$ for one hour. Samples were washed twice with NET-2, resuspended in $500 \mu \mathrm{l}$ NET-2, and $30 \mu{ }^{35} \mathrm{~S}$ extract added. Samples were rotated for one hour at $4^{\circ} \mathrm{C}$, washed six times with NET-2, and the beads resuspended twice in $15 \mu \mathrm{l}$ of Laemmli sample buffer $(0.0625 \mathrm{M}$ trometamol- $\mathrm{HCl}$ buffer $\mathrm{pH} 6 \cdot 8,2 \cdot 3 \%$ SDS, $5 \% \beta$-mercaptoethanol, $10 \%$ glycerol). Standard SDS-polyacrylamide gel electrophoresis was performed according to the method of $\mathrm{Laemmli}^{11}$ with a $17 \cdot 5 \%$ separating gel and a $5 \%$ stacking gel. The gels were processed for autoradiography with enhancement with 2,5diphenyloxazole. Immunoprecipitation was used to identify antibodies to ribosomal RNP, SL/Ki, and $\mathrm{Ku}$ (p70/p80).

\section{Results}

C L I N I C A L

Table 1 shows the clinical manifestations. Fifty two

Table 1 Clinical and laboratory features in 94 patients with SLE at the time of serological analysis

\begin{tabular}{lc}
\hline Clinical/laboratory features \\
\hline Women:men (Nos) & \\
Race (Chinese:Malay:Indian) (Nos) & $86: 8$ \\
Mean age in years (range) & $29 \cdot 7: 4(13-63)$ \\
Mean duration of illness in years (range) & $6 \cdot 14(6-21)$ \\
Active:inactive disease (Nos) & $52: 42$ \\
Active CNS* disease (\%) & 9 \\
Active renal disease (\%) $\dagger$ & 24
\end{tabular}

*CNS = central nervous system.

†Renal disease was indicated by one or more of the following: red blood cells $>5$ per high power field, casts in urine sediment, proteinuria $>500 \mathrm{mg} / 24$ hours, deteriorating creatinine clearance. 
patients had active disease (Table 2). Although renal disease was particularly common, the clinical spectrum included rash, arthritis, serositis, cutaneous vasculitis, and neuropsychiatric disease.

The patients who fulfilled the revised criteria for the classification of SLE had four or more criteria (Table 3). The prevalence of various manifestations

Table 2 Lupus activity criteria

\begin{tabular}{|c|c|}
\hline Criteria according to Urowitz et al ${ }^{3}$ & No of patients \\
\hline Arthritis & 17 \\
\hline Rash & 19 \\
\hline Mucous membrane ulcers & 6 \\
\hline Alopecia & 3 \\
\hline Pleuritis/pericarditis & $8 / 4$ \\
\hline Seizures & 2 \\
\hline Psychosis & 7 \\
\hline Organic brain syndrome & 1 \\
\hline Vasculitis & 5 \\
\hline Haematuria & 3 \\
\hline Proteinuria & 24 \\
\hline LE cell & 1 \\
\hline Total white cell count $<4 \times 10^{9} / l$ & 13 \\
\hline Decreased $\mathrm{CH}_{50}$ or $\mathrm{C} 3$ & 47 \\
\hline Increased dsDNA & 43 \\
\hline
\end{tabular}

Table 3 Prevalence of manifestations in 94 Singapore patients using the 1982 American Rheumatism Association revised criteria for systemic lupus erythematosus ${ }^{2}$

\begin{tabular}{lc}
\hline Criterion & Singapore patients \\
& No (\%) \\
\hline Malar rash & $55 / 94(58)$ \\
Discoid rash & $10 / 94(11)$ \\
Alopecia & $48 / 94(51)$ \\
Photosensitivity & $15 / 94(16)$ \\
Oral ulcers & $18 / 94(19)$ \\
Raynaud's phenomenon & $10 / 94(11)$ \\
Arthritis & $63 / 94(67)$ \\
Proteinuria & \\
$>0 \cdot 5$ g/day & $35 / 94(37)$ \\
$<3 \cdot 5$ g/day & $25 / 94(27)$ \\
Granular casts & $39 / 94(41)$ \\
Dementia & $0 / 94(0)$ \\
Seizure & $14 / 94(15)$ \\
Coma & $1 / 94(1)$ \\
Psychosis & $21 / 94(22)$ \\
Focal neurological disorder & $6 / 94(6)$ \\
Pleurisy & $6 / 94(6)$ \\
Pericarditis & $7 / 94(7)$ \\
Haemolytic anaemia & $12 / 94(13)$ \\
Leucopenia & $53 / 94(56)$ \\
Lymphopenia & $32 / 94(34)$ \\
Thrombocytopenia & $42 / 94(45)$ \\
LE cells & $61 / 89(69)$ \\
Fluorescent antinuclear antibody & $91 / 94(97)$ \\
DNA antibody & $43 / 94(46)$ \\
Sm antibody & $25 / 94(26)$ \\
False positive serological test for syphilis & $11 / 55(20)$ \\
Hypocomplementaemia & $81 / 94(86)$ \\
Pat &
\end{tabular}

was found to be similar for Chinese, Japanese, and American patients except for differences in the prevalence of malar rash, Raynaud's phenomenon, $\overrightarrow{\vec{B}}$ arthritis, psychoses, pleurisy, leucopenia, thrombocytopenia, and DNA antibody (Table 4).

SEROLOGICÁ L IN DINGS

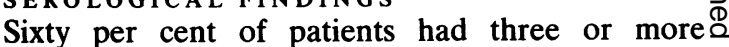
autoantibodies (Figs 1 and 2). The average number of antibodies per patient was $2 \cdot 9$. The most prevalent $\vec{\theta}$ antinuclear antibodies found were those to histones. History of ingestion of hydralazine and procainamide $\vec{\omega}$ before the diagnosis of SLE was not obtained in any patient. Antibodies to SS-A(Ro) were found in $63 \% \frac{\bar{\alpha}}{2}$ of patients. This figure is higher than a Western series, which quotes between 20 and $30 \%$ in the lupus population. ${ }^{12}{ }^{13}$ Patients with central nervous $\overrightarrow{.}$ system (CNS) disease had a greater number of $\stackrel{\infty}{\infty}$

Table 4 Differences in prevalence of certain manifestations in the Singapore patient group, the Japanese group, and the American Rheumatism Association (ARA) patient group. Values are Nos (\%)

\begin{tabular}{|c|c|c|c|}
\hline Criterion & $\begin{array}{l}\text { Singapore } \\
(n=94)\end{array}$ & $\begin{array}{l}\text { Japanese }^{22} \\
(n=285)\end{array}$ & $\begin{array}{l}A R A^{22} \\
(n=177)\end{array}$ \\
\hline Malar rash & $55 / 94(58)$ & $219 / 285$ (77) & 101/177 (5 \\
\hline $\begin{array}{l}\text { Raynaud's } \\
\text { phenomenon }\end{array}$ & $10 / 94(11)$ & $135 / 284(48)$ & $51 / 176(29)$ \\
\hline $\begin{array}{l}\text { Arthritis, } \\
\text { non-erosive }\end{array}$ & $63 / 94(67)$ & $228 / 285(80)$ & $152 / 177(86)$ \\
\hline Pleurisy & $6 / 94(6)$ & $51 / 284(18)$ & $92 / 177(52)$ \\
\hline CNS (psychosis) ${ }^{*}$ & $21 / 94(22)$ & $41 / 285$ (14) & $22 / 176(13)$ \\
\hline Thrombocytopenia* & $42 / 94(45)$ & $68 / 282(24)$ & $37 / 177(21)$ \\
\hline Leucopenia & $53 / 94(56)$ & $191 / 285(67)$ & $82 / 177(46)$ \\
\hline DNA antibody & $42 / 94(45)$ & $244 / 272(90)$ & $113 / 168(67)$ \\
\hline
\end{tabular}

${ }^{*}$ Items CNS/psychosis and thrombocytopenia were added to those $\mathrm{C}$ studied in reference 22 because significant differences were noted in the Singapore population.

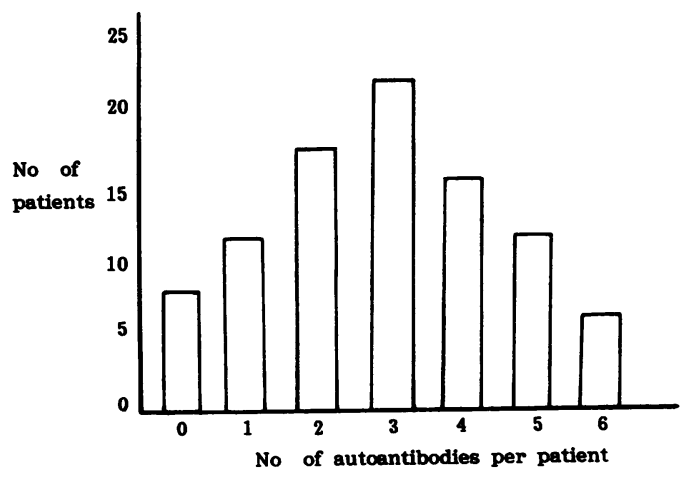

Fig. 1 Number of antibodies detected in 94 patients. 


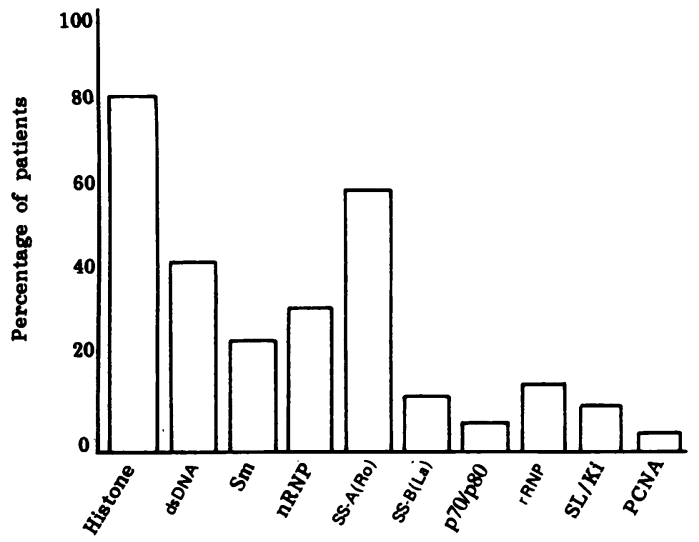

Fig. 2 Autoantibody profile in 94 patients with SLE.

antibodies per patient $(4 \cdot 22)$ than the total population (2.91) and patients without CNS symptoms (2.77). This was reflected in antibodies to dsDNA $(88 \%)$, histones $(100 \%)$, Sm $(77 \%)$, nRNP $(66 \%)$, SS-A(Ro) $(44 \%)$, and rRNP $(22 \%)$ but not in antibodies to SS-B(La), SL/Ki, and p70/p80 (Fig 3, Table 5). This differs from the observation of Bonfa et al, who reported a lower prevalence of antiDNA and anti-Sm in their 18 patients with lupus psychosis who were positive for antiribosomal $\mathrm{P}$ protein antibodies (Table 6). ${ }^{14}$ The CNS disease in our patients was marked by psychosis in six, seizures and focal neurological deficits in three. The male patients with SLE did not differ from the women in clinical manifestations or in severity of disease.

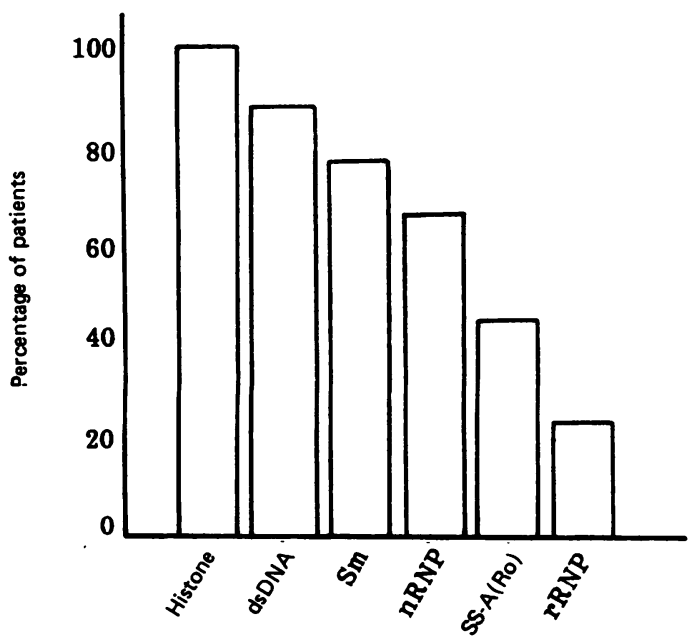

Fig. 3 Antibody profile in nine patients with active central nervous system involvement.
Renal disease was present in 60 patients. Antibodies to SS-A(Ro) were present in $37 \%$ with and $26 \%$ without renal disease $(\mathrm{p}<0 \cdot 15)$ (Table 7$)$. No correlation could be detected between the severity of proteinuria ( $>3.5 \mathrm{~g}$ protein loss being regarded as severe), renal histology, and the number of antibodies present. Although there was a concomitant rise in dsDNA in patients with renal disease, the difference was not significant compared with those without renal disease $(p<0 \cdot 1)$. There was no

Table 5 Immunological correlates in patients with active central nervous system (CNS) disease

\begin{tabular}{|c|c|c|c|}
\hline \multirow{2}{*}{$\begin{array}{l}\text { Antibody } \\
\text { specificity }\end{array}$} & \multicolumn{3}{|l|}{ Prevalence (\%) } \\
\hline & Active CNS disease & Total & population \\
\hline dsDNA & 88 & 43 & \\
\hline $\mathrm{Sm}$ & 77 & 26 & \\
\hline nRNP & 66 & 32 & \\
\hline rRNP & 22 & 16 & \\
\hline p70/p80 & 11 & 5 & \\
\hline Histone & 100 & 81 & \\
\hline \multirow{4}{*}{\multicolumn{3}{|c|}{$\begin{array}{l}\text { Total patients with active CNS disease } \\
\text { Antibody plurality per patient (CNS) } \\
\text { Antibody plurality per patient (total population) }\end{array}$}} & $=9 / 94(10 \%$ \\
\hline & & & $=4 \cdot 22$ \\
\hline & & & $=2.91$ \\
\hline & \multicolumn{3}{|c|}{ Antibody plurality per patient (without CNS symptoms) $=2.77$} \\
\hline
\end{tabular}

Table 6 Serological features in patients with central nervous system (CNS) lupus

\begin{tabular}{lll}
\hline Antibody & \multicolumn{2}{l}{\begin{tabular}{l} 
No $(\%)$ of patients \\
\cline { 2 - 3 }
\end{tabular}} \\
$\begin{array}{lll}\text { New York } \\
(n=18)\end{array}$ & $\begin{array}{l}\text { Singaporet } \\
(n=6)\end{array}$ \\
\hline Anti-DNA & $8(44)$ & $5(83)$ \\
Anti-Ro & $9(50)$ & $1(17)$ \\
Anti-La & $2(11)$ & $0(0)$ \\
Anti-Sm & $6(33)$ & $5(83)$ \\
Anti-RNP & $6(33)$ & $2(33)$ \\
\hline
\end{tabular}

${ }^{*}$ Patients had lupus psychosis and were positive for antiribosomal $P$ protein antibodies. ${ }^{4}$

†Six of nine patients with active CNS disease had psychosis (present study).

Table 7 Immunological correlates in renal disease

\begin{tabular}{|c|c|c|c|c|c|c|}
\hline & \multicolumn{6}{|c|}{ Prevalence $(\%)$ of antibody to: } \\
\hline & $D N A$ & Histone & $S m$ & $n R N P$ & $S S-A$ & $S S-B$ \\
\hline Renal disease & 27 & 48 & 15 & 18 & 37 & 5 \\
\hline Non-renal disease & 20 & 35 & 12 & 15 & 26 & 6 \\
\hline
\end{tabular}


increased prevalence of rash or thrombocytopenia in patients with anti-SS-A(Ro) as observed by some. ${ }^{15} 16$

When the prevalence of other precipitins in patients with SLE with anti-SS-A(Ro) was compared with that of the entire group, there were no appreciable differences. dsDNA was present in 53\% of patients with anti-SS-A(Ro), histones in $90 \%$, nRNP in $33 \%$, SS-B(La) in $22 \%$, and $\mathrm{Sm}$ in $25 \%$.

\section{Discussion}

Our study shows that the prevalence of antinuclear antibodies in Oriental patients was within the range reported from Western countries ${ }^{17}$; the exception being a higher prevalence of antibodies to SS-A(Ro). This indicates a high uniformity of antibody profile in SLE in different populations.

Anti-SS-A(Ro), often accompanied by antiSS-B(La) is found in SLE with a prevalence varying between 20 and $30 \% .{ }^{18}$ These antibodies are found in up to $70 \%$ of patients with primary Sjögren's syndrome and in the sicca complex associated with SLE. ${ }^{19}$ The increased prevalence of this autoantibody in our patients with SLE may indicate the presence of subclinical coexisting Sjögren's syndrome or the likelihood of the future development of sicca symptoms in this subset of patients.

Neuropsychiatric manifestations occurred in $21 \%$ of patients at some time in the course of the disease. There is a tendency for these manifestations to occur early, especially within the first two years of diagnosis. ${ }^{20}$ The higher number of antibodies in these patients may reflect a greater severity of disease. CNS disease is the second commonest cause of death among our patients with SLE. ${ }^{21}$

Anti-Sm antibody occurred in $26 \%$ of patients and was more prevalent in those with active disease ( $36 \%$ in active versus $11 \%$ in inactive disease). This figure is comparable with the Japanese value ${ }^{22}$ but much lower in white patients with SLE. ${ }^{18}$ The association of anti-Sm with anti-RNP is well known and may be related to the association of these antigens in small nuclear ribonucleoprotein particles.

The prevalence of antibodies to rRNP was $16 \%$. This is marginally higher than the reported occurrence of $12 \%$ in patients with SLE. ${ }^{14}{ }^{23}$ No distinctive clinical features were recognised in our patients who were anti-rRNP positive. Anti-rRNP antibodies may be a marker for SLE, being found almost exclusively in SLE, but the clinical significance of these antibodies remains to be determined.

Anti-SL/Ki, p70/p80, and PCNA are uncommon antibodies, and no particular clinical correlation was found with these antibodies. We could not confirm any trend towards increasing cutaneous, haematological abnormalities, or sicca symptoms.
Pertinent to the discussion of the pattern of disease involvement in SLE are selection bias and referral patterns. These two variables could accoun $\overline{\hat{6}}$ for the minor differences observed in our patientso Our patients attended a referral centre for autos immune diseases and their disease tended to $b \overline{\bar{\theta}}$ severe.

We conclude that there is similarity of autoantio body profile among patients with SLE in differenf races and countries, despite differences in severit 9 of disease and mortality in different SLE populations. ${ }^{24}{ }^{25}$ The higher prevalence of anti-SS-A(Ro in our population deserves further study to determine the possible involvement of genetic factors in this situation.

There have been few comprehensive studies of this nature in which a large cohort of patients witip SLE has been analysed for the prevalence of $\overrightarrow{0}$ autoantibodies using recently developed sensitive assays such as ELISA, immunoprecipitation of isotope labelled antigens, and Western blotting. AB interesting feature emerging from this study is that the prevalence of autoantibodies is approximatel similar to previously published data, suggesting tha there is no pool of patients with low levels of autoantibodies. Also, this study calls attention agigino to the fact that SLE is a disease characterised by simultaneous presence of multiple autoantibodies (2.9 per patient), a feature reported many years ago $^{17}$ but not appreciated when attempts are made to associate subsets of clinical features with single्巳 autoantibodies. It would surely be difficult tø associate a clinical picture such as CNS involvemen with a single autoantibody when the average numbe in such patients is $4 \cdot 2$. The observed multiclonality of autoimmune responses in SLE is a phenomenon. whose elucidation should add insights into the nature of the autoimmune process.

\section{References}

1 Tan E M. Autoantibodies to nuclear antigens (ANA): thei immunology and medicine. Adv Immunol 1982; 33: 167-240옹

2 Tan E M, Cohen A S, Fries J F, et al: The 1982 revised criteria for the classification of systemic lupus erythematosus. Arthrit Rheum 1982; 25: 1271-7.

3 Urowitz M B, Gladman D D, Goldsmith C, Tozman E S. Lupus activity criteria count [Abstract]. Arthritis Rheum 1982; 2\% (suppl): S78.

4 Nakamura P M, Peebles C L, Rubin R L, Molden D P, Ta E M. Autoantibodies to nuclear antigens (ANA). 2nd edW Chicago: American Society of Clinical Pathologists Press, 1985O

5 Rubin R L. Enzyme-linked immunosorbent assay for anti-DNA and antihistone antibodies. In: Rose $\mathbf{N}$, Friedman $H$, Fahe J L, eds. Manual of clinical laboratory immunology. 3rd ed@
Washington, DC: ASM, 1986: 744-9.

6 Pollard K M, Tan E M. Purification of the Sm nuclear auto=antigen. Detection and clinical significance of IgM antibody Clin Exp Immunol 1985; 60: 586-96.

7 Tsay S J, Chan E K L, Peebles C L, Pollard K M, Tan E M. A呑 
immunoassay differentiating sera with antibodies to $\mathrm{Sm}$ alone, to Sm/RNP complex and to RNP alone. Arthritis Rheum 1987; 30: 389-96.

8 Chan E K L, Francoeur A M, Tan E M. Epitopes, structural domains, and asymmetry of amino acid residues in SS-B/La nuclear protein. J Immunol 1986; 136: 3744-9.

9 Ogata K, Ogata Y, Nakamura R M, Tan E M. Purification and $\mathrm{N}$-terminal amino acid sequence of proliferating cell nuclear antigen (PCNA)/cyclin and development of ELISA for antiPCNA antibodies. J Immunol 1985; 135: 2623-7.

10 Francoeur A M, Mathews M B. The interaction between VA RNA and the lupus antigen La: formation of a ribonucleoprotein particle in vitro. Proc Natl Acad Sci USA 1982; 79: 6772-7.

11 Laemmli U K. Cleavage of structural protein during the assembly of the head of bacteriophage T4. Nature 1970; 227: 680-5.

12 Maddison P J, Mogavero $\mathrm{H}$, Provost $\mathrm{T} T$, Reichlin $M$. Antibodies to Ro(SSA). The clinical significance of autoantibodies to a soluble cytoplasmic antigen in systemic lupus erythematosus and other connective tissue diseases. I Rheumatol 1979; 6: 189-95.

13 Nakamura R M, Greenwald C A, Peebles C L, Tan E M. Autoantibodies to nuclear antigens (ANA): immunochemical specificities and significance in systemic rheumatic diseases. Chicago: American Society of Clinical Pathologists, Educational Products Division, 1978.

14 Bonfa E, Golombek S J, Kaufman L D, et al. Association between lupus psychosis and anti-ribosomal $\mathrm{P}$ protein antibodies. $N$ Engl J Med 1987; 317: 265-71.

15 Sontheimer R D, Maddison P J, Reichin M, Jordon R E, Stastny P, Gilliam J N. Serologic and HLA associations in subacute cutaneous lupus erythematosus, a clinical subset of lupus erythematosus. Ann Intern Med 1982; 97: 664-71.

16 Morley K D, Berstein R M, Bunn C C, et al. Thrombocytopenia and anti-Ro. Lancet 1981; ii: 940.

17 Notman D D, Kurata N, Tan E M. Profiles of antinuclear antibodies in systemic rheumatic diseases. Ann Intern Med 1975; 83: 464-9.

18 Clark G, Reichlin M, Tomasi T B. Characterization of a soluble cytoplasmic antigen reactive with sera from patients with systemic lupus erythematosus. $J$ Immunol 1969; 102: 117-22.

19 Martinez-Lavin M, Vaughan H, Tan E M. Autoantibodies and the spectrum of Sjögren's syndrome. Ann Intern Med 1979; 91 : 185-90.

20 Feng P H, Boey M L. Systemic lupus erythematosus in Chinese: the Singapore experience. Rheumatol Int 1982; 2: 151-4.

21 Boey M L, Ng S C, Feng P H. Mortality in Orientals with systemic lupus erythematosus. A reappraisal. Singapore Med $J$ 1987; 28: 318-20.

22 Yokugoro R, Tsunematsu T. Application to Japanese patients of the 1982 American Rheumatism Association revised criteria for the classification of systemic lupus erythematosus. Arthritis Rheum 1985; 28: 693-8.

23 Corte's J L, Mendoza F, Reyes P A. Antibodies to ribosomal ribonucleoprotein. Prevalence in systemic rheumatic diseases and partial characterization of the antigen. $J$ Rheumatol 1987; 14: 727-31.

24 Kaslow R A. High rate of death caused by systemic lupus erythematosus among US residents of Asian descent. Arthritis Rheum 1982; 25: 414-8.

25 Rosner S, Ginzler E M, Diamond H S, et al. A multicentre study of outcome in SLE. Causes of death. Arthritis Rheum 1982; 25: 612-7. 